\title{
INTERNET INTERNET
}

UYGULAMALARI Ve YÖNETIMI APPLICATIONS and MANAGEMENT

$2020 / 11(2)$

\section{Fearing Coronavirus: The Role of Digital Health News Consumption and Competence}

\section{Coronavirüsten korkmak: dijital sağlık haberi tüketiminin ve dijital yetkinliğin süreçteki rolü}

\author{
Vehbi GÖRGÜLÜ 1, vehbi.gorgulu@bilgi.edu.tr
}

Received: 05.08.2020; Accepted: 17.12.2020

The coronavirus (also referred as COVID-19 or coronavirus disease 2019) has become one of the major global health concerns around the world, as the geographies effected by the virus increases, as a result of social mobilities. The digital media outlets such as news platforms and online social networks play a key role in terms of informing the online audiences by raising awareness regarding the disease, while sometimes the opposite can be the case due to contents triggering societal panic at global level. The current study aims to explore potential relationships between digital literacy, digital health news consumption, and the fear of coronavirus, by applying a quantitative research perspective. A total of 587 respondents were reached online via the pilot-tested survey instrument. Following the removal of missing submissions, 467 participants remained. It is concluded that digital competency has a positive relationship with digital health news consumption, which means as digital literacy increases, the frequency of digital health news consumption practices rises up in return. Another important finding is related to fear felt towards coronavirus, as findings also indicate as the level of digital health news consumption increases, the fear felt towards coronavirus also escalates. This finding indicates the essentiality of providing accurate news for the Internet audiences, that raises awareness rather than triggering social anxiety and panic.

Keywords: COVID-19, Health Communication, Digital Literacy, Outbreak, Panic
Coronavirüs (COVID-19 veya coronavirüs hastalı̆ğ 2019 olarak da anılmaktadır), 2020 yılı itibariyle küresel ölçekte en çok endişe uyandiran hastalıklardan biri haline dönüşmüş̧ür. Bu endişede, virüsün günlük sosyal etkileşimle hızl bir şekilde yayılma potansiyeli ve sosyal mobilizasyonun küresel ölçekteki yoğunluğu büyük bir rol oynamaktadır. Süreçte, dijital haber platformları ve sosyal ağlar, enformasyon paylaşımı bağlamında etkin bir öneme sahipken, bu paylaşımlar zaman zaman sosyal paniğin küresel ölçekte tetiklenmesiyle de sonuçlanabilmektedir. Mevcut çalışma, dijital yetkinlik, dijital sağlık haberi tüketimi ve coronavirüse yönelik duyulan korku arasindaki ilişkiyi kantitatif araştırma perspektifi içerisinde incelemektedir. Bu doğrultuda, geliştirilen ve ön test uygulaması yapılan anket çalışması aracılığıyla, toplamda 587 kişiye ulaşılmıştır. Eksik yanıtların yer aldığı anketlerin veri setinden çıkarılması sonucu edinilen örneklem 467 kişiden oluşmaktadır. Araştırmanın bulguları, dijital yetkinlik ve dijital sağlık haberi tüketimi arasında anlaml bir ilişki olduğunu göstermekte, bu durum, dijital araçlar tanıyan ve bu araçların kullanımında daha yetkin olan kişilerin, dijital sağlık haberlerini daha sık bir biçimde takip ettiklerine işaret etmektedir. Bir diğer önemli bulgu, dijital să̆lik haberi tüketimi ile coronavirüse yönelik duyulan korku arasındaki anlamlı ilişkidir. Daha çok dijital să̆lık haberi okuyan internet kullanıcısı bireylerin hastahı̆̆a yönelik duydukları korku da paralel biçimde artış göstermektedir. Bu bulgu, dijital haber mecralarmm etki boyutunun büyüklü̆̆̈̈ne işaret ederken, aynı zamanda haber üretim süreçlerinde sosyal bilince vurgu yapılmasının ve panik ortamının tetiklenmesinden kaçınılmasının gerekliliğine işaret etmektedir.

Anahtar Kelimeler: COVID-19, Sağlık İletişimi, Dijital Yetkinlik, Salgin, Panik

\footnotetext{
${ }^{1}$ Istanbul Bilgi University, Department of Communication Design and Management
} 


\section{INTRODUCTION}

China branch of World Health Organization (WHO) was notified regarding the first report that was caused by an unknown virus, which resulted several pneumonia cases in Wuhan city of China on December 31, 2019 (Reynolds and Weiss, 2020). What once remained a mystery, turned into an international pandemic in a short period of time. It was announced that confirmed cases were approximately 18 million, while death cases were around 670.000 worldwide by the end of July 2020 (World-o-meter, 2020). Although more than 10 million cases were closed due to recoveries, coronavirus resulted with the emergence of anxiety and fear at global level due to the high number of death rates. In order to prevent further spread, the majority of countries with high rates of COVID-19 cases had to take precautionary measures to protect the rest of the populations from the disease.

It was March 11, 2020 when Turkish Health Minister Fahrettin Koca announced the first case of novel coronavirus, who contracted the disease while returning from a trip to Europe (Zorlu, 2020). As a result, precautionary actions were immediately taken in Turkey: Schools and universities were shut down, online education started and the majority of private sector employees started working home office. Night clubs were closed down and social events were cancelled or delayed to prevent individuals from gathering in social spaces in high numbers. The COVID-19 virus reached its first peak in late April 2020 in Turkey, while the number of daily cases started to decrease gradually until late July the same year. Precautionary measures were effective in terms of reducing the number of daily new cases, as Turkish citizens were encouraged to stay at their homes and self-isolate themselves during certain critical periods. The normalization process began in May 2020, when shopping malls and beauty centers started accepting customers after receiving government permission (Anonymous reporter a, 2020).

The spread of the coronavirus, the ever-increasing number of deaths and the World Health Organization's announcement of an emergency put a huge burden on the messenger's shoulder (World Health Organization, 2020). The messenger has been the media institutions, who have had a critical role in terms of disseminating critical news to their audiences. However, the process has brought along several challenges. In addition to the dissemination of fake news and misleading contents, many of which became viral on social media, click hunting remained at the focus of several digital media entrepreneurs to draw more readers to their news platforms throughout the process.

In the coronavirus outbreak, information pollution has spread faster than the virus in certain global media outlets (Axt et al., 2020). One of the false claims regarding the coronavirus has been is that it was developed as a biological weapon to reduce the number of world population (Kaszeta, 2020). In order to prevent the emergence of fear and panic in digital media platforms, Turkish government has taken precautionary steps, as a group of officers from Turkish Ministry of Interior were assigned the duty to spot fake news being spread in social media (Anonymous reporter b, 2020).

During extraordinary experiences such as pandemics, it is important to act in the light of information provided by health officials, health ministries and non-governmental organizations such as World Health Organization (WHO). Digital literacy and competence stand as key factors at this point, for guiding individuals to relevant and reliable news 
resources. In line of these developments, the current study aims to explore the potential relationships between digital literacy, digital health news consumption and the fear felt towards the novel coronavirus.

\section{LITERATURE REVIEW}

\subsection{The Fear of Disease and Stigmatization}

Emotions are heavily influenced by their sociocultural context. While certain emotions can guide individuals to a psychologically happier state of mind, the opposite scenario can be the case if individuals are surrounded by a negative emotional environment. In terms of sensitive social phenomenon such as pandemics, individuals are naturally inclined towards fear (Van Brakel, 2006: 307). The fear towards the disease stems from disease-phobia. This situation results with the perception of diseased individuals as potential social threats and stigmas (Sontag, 2015: 54).

The previous literature indicates that psychiatric patients compose the majority group who are mostly affected by the stigmatization. Stigma is a condition that affects an individual's psychiatric state and prevents her/him from receiving medical help. Stigmatized individuals perceive their disease as personal weakness and deny their health condition unconsciously (Link and Phelan, 2006). The denial of the disease results with social avoidance, as the diseased individuals gradually isolate themselves from their social environments. Stigmas evolve and change from culture to culture; however, previous studies indicate they remain the same in each society when it comes to psychological disorders (i.e. Mak et al., 2006).

According to Link and Phelan (2006), the stigmatization takes place through three social mechanisms (p. 528): Stigmatization from person to person, structural stigmatization and selfstigmatization. Stigmatization from person to person occurs, when an individual is accused of his/her action of catching the disease. Structural stigmatization emerges, when an individual is discriminated by social institutions due to her/his health condition. Lastly, selfstigmatization takes place when an individual accuses herself/himself and internalizes the negative attributes made by the society.

The people effected by the coronavirus are also under threat of being stigmatized, since even a slight interpersonal contact between an infected and a healthy individual can result with the transmission. The media outlets play a key role in terms of informing the online audiences by raising awareness regarding the disease, rather than growing the culture of fear and stigmatization. As the experience with AIDS outbreak revealed, hospital employees such as doctors and nurses developed AIDS-stress and/or AIDS-phobia while treating individuals in 1980s. The phobia emerged due to lack of informative resources, as 1980s was the time when little information about AIDS syndrome was available (Harrell \& Wright, Jr., 1998). A similar situation is being experienced with COVID-19, since the majority of information regarding the structure of virus remains unknown. For example, doctors from the United Kingdom were the first group of medical professionals in the world to threaten to quit their job as they claimed they have not been provided enough safety equipment to protect themselves from the virus (Colson, 2020). A similar resentment was made by the nurses in the United States, as 79 nurses lost their lives for contracting the virus while treating the infected patients (Ali, 2020). 
Disease outbreaks are not new phenomenon. Several outbreaks were experienced in the recent history with the spread of a virus called Severe Respiratory Acute Syndrome (SARS) in 2003, H1N1 virus (bird flu) in 2009 and Western Africa Ebola virus between 2013 and 2016. SARS was a main concern especially in Asian countries, while Ebola virus was a serious threat in African countries such as Liberia and Sierra Leone. Thus, these viruses were mainly affecting certain geographies. From this sense, the spread of coronavirus remains as a novel experience, for emerging as a global threat whose impact spans continents such as Africa, Asia and Europe.

Coronavirus is a symptomatic disease. The symptoms of coronavirus are reported to be dry cough, fever, weakness, sore throat, runny nose, body aches, pneumonia, respiratory distress, shortness of breath, diarrhea, nausea, vomiting and loss of appetite (World Health Organization, 2020). The coronavirus can reach the respiratory system through airborne droplets, as a result of sneezing and coughing, similar to flu infections caused by the influenza virus. By touching the surfaces carrying the virus, the mouth and eyes of individuals can also be infected. WHO (2020) state that symptoms of virus transmission can show up within 14 days after contracting the virus.

In Turkey, Ministry of Health provided online guidelines for several actors that would potentially be affected by the coronavirus, such as enterprises and health institutions (T.C. Ministry of Health, 2020). The Ministry also launched a website to share specific information regarding coronavirus, where support mechanisms, evaluation reports and precautionary measures were explained in detail (covid19bilgi.saglik.gov.tr, 2020). An additional web site, called "Hayat Eve Sığar" was launched to enable Turkish citizens register for a HES code, which serves to reduce the risk of contamination, that individuals can encounter during the times they spend in transportation vehicles (hayatevesigar.saglik.gov.tr, 2020). The web site, which is accompanied by a mobile application, also informs individuals about individuals contracted by the virus that lives nearby (hayatevesigar.saglik.gov.tr, 2020).

\subsection{Digital Literacy and Competence}

Internet studies have remained at the focus of communication researchers since 1990s (Livingstone and Bovill, 2001). The primary studies (1997-2005) applied a positivist approach in order to explore Internet usage patterns of individuals (Davies, Coleman and Livingstone; 2014), while the second period (2015-2010) focused on various social and economic sub-groups to reach more detailed insights (Livingston et al., 2012). With the increasing number of online social networks, post-2010 studies focused on specialized themes such as online privacy, digital literacy, education, consumption patterns and user experience (James et al., 2009). For example, James et al. (2009) focused on the potential of Internet to transform educational processes, while also investigating ethical concerns. Additionally, Jenkins et al. (2009) explored how new media technologies enable participatory cultures on the Internet. Researchers stated that participatory cultures are formed by individuals who obtain a certain degree of skills related with digital literacy. These skills include competence for the use of computers and the Internet technologies, as well as research capabilities regarding different topics such as health, entertainment and news.

In Turkey, The Digital Transformation Project in Higher Education was launched in November 2018, which included 8 pilot universities. The pilot study started with the 
introduction of the Digital Literacy course to first, faculty members of 16 universities in July 2019, and then to the students of these faculty members (Sezgin \& Karabacak, 2020).

The importance of digital literacy theme was also emphasized by the industry professionals. In 2017, Turkey Industry \& Business Association (TÜSİAD) summarized the importance of digital competence by stating that digital literacy can only be achieved at the desired level if companies, the government and academicians collaborate for digital transformation (TÜSİAD, 2017: 69).

Previous research reveals that there is a load of misinformation and disinformation being spread on the Internet. For example, the study by Ünal and Taylan (2017) found out that verification is a major concern on online health related news, while also emphasizing the majority of information being shared via mobile chat application WhatsApp remains misleading (p. 97). Additionally, the study of Ertaş et al. (2019) explain that there is a significant relationship between digital literacy and e-health news literacy. The findings of Ertaş et al. (2019) indicate that digitally literate individuals are more competent with selecting the reliable e-health news sources online. The current research aims to include the factor of fear in this process, to contextualize its perspective in terms of epidemics and the potential culture of virus-phobia on the Internet.

\subsection{Communicating health: Digital health news}

Communication research has two main focus: Examining the production of human communication (e.g. communication forms, communication channels and message features) and the effects of communication on people (Feeley and Chen, 2013) While examining the communication process, both how the communication is produced and the effect of communication on people should be analyzed. Health communication is also a type of subcommunication where these two focuses apply.

The U.S. Department of Health and Human Services defines health communication as "the art and technique of informing, influencing and motivating individual, institutional and public audiences about important health issues" (Anon, 2000). Çınarlı states (2008) that health communication includes the purpose of obtaining information, which is defined as the process of obtaining information about the health status of those who receive health care (p. 40). Sezgin (2010) underlines the same point explaining that health communication is related to "raising awareness of individuals, institutions and societies about health communication in health and health issues, eliminating the need for information; to provide accurate information; building health awareness; creation and development of health literacy (p. 117). Based on these definitions, it can be said that health communication is a process that aims to raise awareness about health and fostering health literacy. As Picard and Yeo (2011) explain, health is a highly relevant theme both for individuals and the general public because issues have distinct effects on individuals, families, and community health and well-being.

Health communication is critical in terms of creating public awareness. As Prilutski (2010) suggests, who explains how the Ghanaian health communication conducted by the government reached success in combating infectious diseases, "health communication plays a vital role in public health campaigns designed to prevent infectious diseases in developing countries" (2010: 51). In this example, successful communication has been established with 
"community integration and cultural familiarity" (Prilutski, 2010). In fact, this applies to each of the effective health communication cases. Effective communication, whether directly with the public or via the media, requires understanding the cultural norms of that society and providing information in accordance.

Digital technologies also transform the way individuals engage with health communication. As Doğanyiğit and Peltekoğlu (2019) state, "today, many patients and caregivers participate in social support groups via computers", which indicates that "online social support groups will have a significant impact on people's health-related decisions in the future" (p. 97). Similarly, Yılmaz Altuntaş (2019) argues that digital technologies will offer a more personalized health service experience for individuals as a certain group of inpatient treatments will transform into online home-treatment operations (p. 32). Thus, it can be foreseen for the near future that online health consultancy services will witness a rise in number.

Health is a social field that is constantly in progress thanks to the scientific studies and developments. Hence, approaches in health communication also need to be updated constantly. As Sezgin explains, "one of the most crucial goals of health communication is to inform individuals on health-related topics, increase their awareness on these topics and lead them towards the right behaviors" (Sezgin, 2010: 118). The main logic behind this goal is that, if the awareness of the individuals can be raised, they can work on themselves to improve their health conditions. With an effective health communication strategy, individuals can easily be motivated to monitor their own wellness. Thus, correct strategies should be enacted not only by health institutions and governments, but also by media institutions that deliver health news contents to the Internet users.

\section{METHODOLOGY}

As COVID-19 emerged as a serious threat that challenge the health of world population, it quickly became a trending topic not only on mainstream media outlets, but also on online social networks and news providers. In line with this situation, the current study aims to explore the relationship between digital literacy, digital health news consumption and the fear felt towards the virus. The current study is conducted by embracing a quantitative research approach and applying survey method. The data was collected online to prevent participants from feeling social anxiety due to COVID-19 risk infection. Table 1 represents the measures of the study and their Cronbach Alpha's values $(\alpha>0.7$ for each), revealing that the selected measures strongly reflect the dependent and independent variables.

Table 1. Measures of the study

\begin{tabular}{lccccccc}
\hline $\mathbf{n}=\mathbf{4 6 7}$ & & Min & Max & $\mu$ & SD & Items & $\alpha$ \\
\hline $\begin{array}{l}\text { Independent } \\
\text { variables }\end{array}$ & Digital literacy & 1 & 5 & 3,67 &, 71 & 10 & 0,89 \\
\cline { 2 - 8 } & Digital news consumption & 1 & 5 & 3,44 &, 76 & 10 & 0,81 \\
\hline $\begin{array}{l}\text { Dependent } \\
\text { variable }\end{array}$ & Fear of coronavirus & 1 & 5 & 3,86 &, 66 & 38 & 0,94 \\
\hline
\end{tabular}




\subsection{Data Collection Instruments}

For measurement of independent variables, the digital literacy scale is adopted from NG (2012), which is composed of 10 items (i.e., "I am confident with my searching and evaluation skills in regards to obtaining information from the Internet) and 10 item digital news consumption scale is adopted from Fletcher and Park (2017), to learn about patterns about participants' news participation. The 38-item perceived felt towards coronavirus was adopted from Arrindell et al. (1989) (i.e. I have a fear of contracting coronavirus"," I have a fear of having casual contact with a coronavirus victim") for the measurement of the dependent variable.

The Internet-based survey instrument was pilot tested with the voluntary participation of 25 individuals before the actual fieldwork online. A total of 587 respondents took part in the survey study. Following the removal of submissions with missing data from the set, 467 participants ( $59.2 \%$ females and $40.8 \%$ males) remained in the main analysis. All participants were aged 18 and older and the average age of the participants was 30 . The data based on random sampling was compiled between March-May 2020, by utilizing from online social network, Facebook and its "Groups" in-built feature.

\subsection{Findings}

Pearson Product-moment correlations (with pair-wise exclusion of missing cases) were conducted in order to reveal the correlations between dependent and independent variables. The analysis revealed that the dependent variable and the independent variables are positively correlated (Table 2).

Table 2. Correlation matrix $(n=467)$

\begin{tabular}{|c|c|c|c|c|}
\hline & & & Digital health & \\
\hline & & Digital literacy & $\begin{array}{c}\text { news } \\
\text { consumption }\end{array}$ & Fear of Coronavirus \\
\hline \multirow{3}{*}{ Digital literacy } & Pearson Correlation & 1 & $.360^{* *}$ & $.317^{* *}$ \\
\hline & Sig. (2-tailed) & & $<, 001$ & $<, 001$ \\
\hline & $\mathrm{N}$ & 467 & 4 & 467 \\
\hline \multirow{3}{*}{$\begin{array}{l}\text { Digital health } \\
\text { news } \\
\text { consumption }\end{array}$} & Pearson Correlation & $.370^{* *}$ & 1 & $.263^{* *}$ \\
\hline & Sig. (2-tailed) & $<, 001$ & & $<, 001$ \\
\hline & $\mathrm{N}$ & 467 & 467 & 467 \\
\hline \multirow{3}{*}{$\begin{array}{l}\text { Fear of } \\
\text { coronavirus }\end{array}$} & Pearson Correlation & $.347^{* *}$ & $.232^{* *}$ & 1 \\
\hline & Sig. (2-tailed) & $<, 001$ & $<, 001$ & \\
\hline & $\mathrm{N}$ & 467 & 467 & 467 \\
\hline
\end{tabular}

To assess the relative predictive values, two separate linear regression analyses were conducted between digital literacy (as independent variable)- (as dependent variable) and digital news consumption (as independent variable) and fear of the coronavirus (as dependent variable). 
Table 3. Findings of the regression analyses

\begin{tabular}{llcccccc}
\hline $\begin{array}{l}\text { Independent } \\
\text { variable }\end{array}$ & $\begin{array}{l}\text { Dependent } \\
\text { variable }\end{array}$ & B & SE & $\mathbf{t}$ & Sig & F & Adj. $\mathbf{R}^{2}$ \\
\hline Digital literacy & $\begin{array}{l}\text { Digital health } \\
\text { news } \\
\text { consumption }\end{array}$ &, 492 &, 052 & 7.071 & $<, 001$ & 45.225 &, 166 \\
\hline $\begin{array}{l}\text { Digital health } \\
\text { news } \\
\text { consumption }\end{array}$ & $\begin{array}{l}\text { Fear of the } \\
\text { coronavirus }\end{array}$ &, 474 &, 088 & 5.571 & $<, 001$ & 30.109 &, 087 \\
\hline
\end{tabular}

Findings revealed digital literacy determined digital news consumption patterns, while digital news consumption determined the fear of the coronavirus. This finding reveals that digital news sources individuals are following are determined by their digital literacy level. Moreover, digital news sources individual follow determines their perception of the COVID19 outbreak. The $B$ coefficients indicate the highest relationship between digital literacy and digital health news consumption ( $(=, 492, \mathrm{t}=7.071, \mathrm{p}<, 001)$, followed by the relation between digital health news consumption and fear of the coronavirus $(\beta=, 474, t=5.571, p<, 001)$.

\section{CONCLUSION}

COVID-19 emerged as a major concern for the global society at the eve of 2020. After the first individual contracted the coronavirus was identified in Wuhan, China, the virus quickly spread into the other regions of the city, as well as to the other countries. The virus did not only emerge as a threat against the global health, but also against the effective operation of many industries. For instance, online flight and hotel bookings decreased almost by half and the majority of world's companies had to face challenging uncertainties (Comscore, 2020). Ecommerce industry emerged as an exception during this period, as online shopping platforms such as Amazon immensely increased their profit as a consequence of social isolation (Neate, 2020).

Communities often face problems. As it has been with the COVID-19 case, some of these problems suddenly appear in local societies, but turn into global issues. During such incidents, media plays a crucial role in terms of informing the audiences regarding the ongoing events. It is ethically necessary for the media institutions to inform citizens with a clear voice, by abstaining from misleading information. However, the COVID-19 experience revealed that sometimes this process may result with deeper hysteria and anxiety due to the controversial contents offered by global news providers.

The coronavirus case reveals that moral panic and media have a symbiotic relationship. When a news provider prioritizes making profits and receiving more clicks or constantly looking for a controversial angle of a fragile story, the emergence of fear and anxiety culture on the Internet is inevitable. The fact that fear stands out as a theme in the coronavirus reports shows that much of the scope of the outbreak is a reflection of public fear rather than informing what actually happened in terms of the spread of the virus.

The findings of the current research prove that digitally competent individuals are more into consuming health news on digital platforms, which in turn triggers social fear and moral panic. In order to overcome such culture of anxiety, digital media platforms should embrace 
an informative role that equip the audiences with useful information for taking measures to protect themselves against the novel coronavirus.

The findings of the current study also indicate that there are several research avenues that are worth for exploration. Previous research has found that fear of missing out (FOMO) is highly relevant with social media addiction and lower life satisfaction (Przybylski et al., 2013). FOMO is defined as a form of social anxiety that stems from the belief that an interesting event might be happening on social media, while the individual is not online. Thus, future research can explore whether individuals with higher levels of digital literacy and competence are also experiencing FOMO, which may cause them to consumer more news contents and feel higher levels of anxiety in return.

\section{REFERENCES}

Ali, S. S. (2020, May 10). Why Some Nurses Have Quit During The Coronavirus Pandemic. NBCNews, Accessed 06 June 2020, URL: https://www.nbcnews.com/news/usnews/why- Some-nurses-have-quit-during-coronavirus-pandemic-n1201796

Anonymous reporter a. (2020, March 08). Turkish Cyber Police to Curb Fake News on Coronavirus. Daily Sabah, Accessed 13 April 2020, URL:https://www.dailysabah.com/turkey/turkish-cyber-police-to-curb-fake-news-on coronavirus/news

Anonymous reporter b. (2020, March 03). Coronavirus Cases Top 92,000: Live Updates on COVID-2019. Live Science, Accessed 14 May 2020, URL: https://www.livescience.com/coronavirus-updates.html

Arrindell, W.A., Ross, M.W., Bridged, K.R., van Hout, W., Hofman, A., \& Sanderman, R. (1989). Fear of Aids: Are There Replicable, Invariant Questionnaire Dimensions? Advances in Behaviour Research and Therapy, 11(2), 69-115.

Axt, J.R., Landau, M.J. \& Kay, A.C. (2020). The Psychological Appeal of Fake News Attributions. Psychological Science, https://doi.org/10.1177/0956797620922785

Cinarli, I. (2008). Science and health news. Eğitim Kitabevi.

Colson, T. (2020, March 25). UK Doctors Are Threatening To Quit Because They Have Not Been Given Enough Safety Equipment To Protect Them From The Coronavirus. Business Insider, Accessed 06 May 2020, URL: https://www.businessinsider.com/coronavirus ukdoctors-threaten-to-quit-over-lack-of-protective-equipment-2020-3

Comscore. (2020). Consumer Interest in Travel Categories Remains Significantly Lower. Accessed 06 May 2020, URL: https://www.comscore.com/Insights/Press Releases/2020/4/Consumer-Interest-in-Travel-Categories-Remains-Significantly Lower 
COVID-19 Yeni Coronavirüs Hastalığı. (2020). Accessed 13 July 2020, URL: https://covid19bilgi.saglik.gov.tr/tr/

Davidson, C.N., Goldberg, D.T., \& Jones, Z.M. (2009). The Future of Learning Institutions in a Digital Age. THE MIT Press.

Davies, C., Coleman, J., \& Livingstone, S. (2014). Digital Technologies in the Lives of Young People. Routledge.

Doğanyiğit, S. Ö. \& Peltekoğlu, F.B. (2019). Level of Engagement in Online Social Support Websites in Healthcare Communication: A Study in Usage Behaviors of Ca Patients. Hire, 2(2), p. 96-117.

Ertaş, H., Kıraç, R. \& Demir, R.N. (2019). Dijital Okuryazarlık ve E-Sağglk Okuryazarlı̆̆ı Arasındaki İlişkisinin İncelenmesi. 3. Uluslararası 13. Ulusal Sağlık ve Hastane İdaresi Kongresi Bildirileri, 557-570.

Feeley, T. H. \& Chen, C. (2013). An Introduction to Health Communication. In Principles of Communication: Readings in Communication. Hayden McNeil.

Fletcher, R. \& Park, S. (2017). The Impact of Trust in the News Media on Online News Consumption and Participation. Digital Journalism, 5(10). 1281-1299.

Harrell, J. P. \& Wright, Jr., L. W. (1998). The Development and Validation of the Multicomponent Aids Phobia Scale. Journal of Psychopathology and Behavioral Assessment, 20(3), 201-216.

Hayat Eve Sığar Resmi İnternet Sitesi. (2020). Accessed 12 July 2020, URL: https://hayatevesigar.saglik.gov.tr/

Jenkins, H., Purushtoma, M.W., Clinton, K. \& Robinson, A.J. (2009). Confronting the Challenges of a Participatory Culture: Media Education for the 21st Century. The MIT Press.

Kaszeta, D. (2020, April 27). No, The Coronavirus Is Not A Biological Weapon. The Washington Post, Accessed 29 May 2020, URL: https://www.washingtonpost.com/outlook/2020/04/26/no-coronavirus-is-not biologicalweapon/

Link, B. G. \& Phelan, J. C. (2006). Stigma and Its Public Health Implications. Lancet, 367, 528529.

Livingstone, S. \& Bovill, M. (2011). Children and Their Changing Media Environment: A European Comparative Study. Hillsdale, N.J.: Lawrence Erlbaum.

Livingstone, S. (2002). Young People and New Media: Childhood and the Changing Media Environment. London: Sage.

Livingstone, S., Haddon, L. \& Görzig, A. (2012). Children, Risk and Safety on the Internet. Bristol: The Policy Press.

Livingstone, S. \& Haddon, L. (2009). Kids Online: Opportunities and Risks for Children. The Policy Press. 
Mak, W. W. S., Mo, P. K. H., Cheung, R. Y. M., Woo, J., Cheung, F. M., Lee, D. (2006). Comparative Stigma of HIV/AIDS, SARS, and Tuberculosis in Hong Kong. Social Science E Medicine, 63(7), 1912-1922.

Neate, R. (2020, July 21). Jeff Bezos, the world's richest man, added $£ 10 \mathrm{bn}$ to his fortune in just one day. The Guardian, Accessed 01 August 2020, URL: https://www.theguardian.com/technology/2020/jul/21/jeff-bezos-the-worlds-richest man-added-10bn-to-his-fortune-in-just-one-day

NG, W. (2012). Can We Teach Digital Natives Digital Literacy? Computers E Education, 59(3), 1065-1078.

Picard, R. G. \& Yeo, M. (2011). Medical and Health News and Information in the UK Media: The Current State of Knowledge. Oxford: University of Oxford Reuters Institute for the Study of Journalism.

Prilutski, M. A. (2010). A Brief Look at Effective Health Communication Strategies in Ghana. The Elon Journal of Undergraduate Research in Communications, 1(2), 51-58.

Reynolds, M. \& Weiss, S. (2020, May 27). How Coronavirus Started and What Happens Next, Explained. Wired, Acccessed 03 June 2020, URL: https://www.wired.co.uk/article/chinacoronavirus

Rivers, C. \& Watson, C. (2020, February 2020). Why We Still Don't Know How Deadly This New Coronavirus Is. Vox, Accessed 03 March 2020, URL: https://www.vox.com/2020/2/12/21134718/coronavirus-china-deaths-mortality-rate

Sezgin, D. (2010). Sağlık Iletişimi Paradigmalari ve Türkiye: Medyada Sağlık Haberlerinin Analizi. T.C. Ankara Üniversitesi Sosyal Bilimler Enstitüsü Halkla İlişkiler ve Tanıtım Anabilim Dalı.

Sezgin, A.A. \& Karabacak, Z.A. (2020). Yükseköğretimde Dijital Dönüşüm ve Dijital Okuryazarlık Dersine Yönelik Betimsel Bir Analiz. Anadolu Üniversitesi İletişim Bilimleri Fakültesi Uluslararası Hakemli Dergisi, 28(1), p. 17-30.

Sontag, S. (2015). Metafor Olarak Hastalık: AIDS ve Metaforları. (Cev: O. Akınhay). Istanbul: mCan.

T.C. Ministry of Health Official Website. (2020). Accessed 06 May 2020, URL: https://sbsgm.saglik.gov.tr/

TÜSİAD (2017). Türkiye'nin Sanayide Dijital Dönüşüm Yetkinliği. Nurşen Numanoğlu, F. Hazal İnce (edt.), İstanbul

Ünal, R. \& Taylan, A. (2017). Sağlık İletişiminde Yalan Haber-Yanlış Enformasyon Sorunu ve Doğrulama Platformları. Atatürk Illetişim Dergisi, 14, 81-100.

Van Brakel, W. H. (2006). Measuring Health-Related Stigma-A Literature Review. Psychology, Health \& Medicine, 11(3), 307-334.

World Health Organization. (2020). Accessed 13 July 2020, URL: http://www.who.org 
World-o-Meter. (2020). COVID-19 Coronavirus pandemic. Accessed 01 August 2020, URL: https://www.worldometers.info/coronavirus/

Yılmaz Altuntaş, E. (2019). Sağllk Hizmetleri Uygulamalarında Dönüşüm. Eğitim KitabeviYayınları.

Zorlu, F. (2020, March 11). Turkey Confirms First Case of Coronavirus. Anadolu Agency, Accessed 11 April 2020, URL: https://www.aa.com.tr/en/latest-on-coronavirus outbreak/turkey-confirms-first-case-of-coronavirus/1761522 